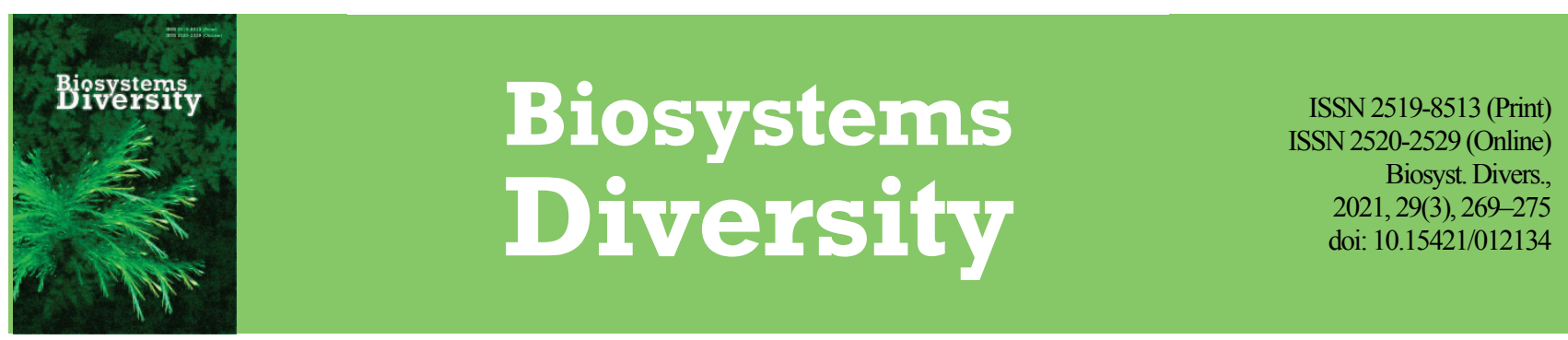

\title{
Local taxonomic spectra in plants, animals, fungi and terrestrial protists show common mathematical patterns
}

\author{
D. V. Leontyev*, I. I. Yatsiuk**, T. Y. Markina*, L. P. Kharchenko*, \\ E. V. Tverdokhleb*, I. O. Fedyay***, Y. A. Yatsiuk** \\ *H. S. Skovoroda Kharkiv National Pedagogical University, Kharkiv, Ukraine \\ **Institute of Ecology and Earth Sciences, University of Tartu, Tartu, Estonia \\ ***Kharkiv State Academy of Physical Culture, Kharkiv, Ukraine
}

Article info

Leontyev, D. V., Yatsiuk, I. I., Markina, T. Y., Kharchenko, L. P., Tverdokhleb, E. V., Fedyay, I. O., \& Yatsiuk, Y. A. (2021).

Received 28.06.2021 Local taxonomic spectra in plants, animals, fungi and terrestrial protists show common mathematical patterns. Biosystems DiReceived in revised form 20.07.2021 versity, 29(3), 269-275. doi:10.15421/012134

Accepted 21.07.2021

H. S. Skovoroda Kharkiv National Pedagogical University

Valentynivska st., 2

Kharkiv, 61168, Ukraine

Tel.: +38-099-644-17-81.

E-mail:alwisiamorula@gmail.com

Institute of Ecology and Earth

Sciences, University of Tartu,

Vanemuise, 46, Tartu, EE-51005,

Estonia. Tel.: +372-737-51-00.

E-mail:iryna.yatsiuk@ut.ee

Kharkiv State Academy of Physical

Culture, Klochkivska st., 99,

Kharkiv, 61058, Ukraine.

Tel.: +38-057-705-23-01.

E-mail: razira1983@gmail.com

Taxonomic spectra, i.e. relations between supraspecific taxa by the number of included species, remain poorly understood in aspect of the mathematical properties. We studied taxonomic spectra of plants (Magnoliophyta, Bryophyta), animals (Coleoptera, Aves), fungi (Agaricomycetes) and terrestrial protists (Myxomycetes), found in the Homilsha Forests National Nature Park (NorthEast of Ukraine), and concluded that they correspond to the hollow-curve distribution at the level of genera, families and orders. The spectra of most taxa, as shown by the Akaike information criterion, are closely approximated by the log-series distribution model at all taxonomic levels. This type of distribution is typical for the species abundance curves, based on collections made from small areas. At the same time, in the genera-families-orders row the similarity to the lognormal distribution increases. The central values and variability vary considerably between different taxonomic groups and ranks, however, without affecting the type of distribution. The number of orders in all taxa except Bryophyta has reached the saturation and coincides with the curve of the estimated number of orders according to the Chaol coefficient. For families and especially genera the correspondence with estimated number of species is much lower. Our results do not confirm the assumption that hollow-curve distributions of taxonomic spectra result from the artificial fragmentation of taxa. These distributions neither depend on the insufficient knowledge about the species composition at the locality, nor reflect the size of the studied area. The presence of such distributions in both local and global biota of different groups may be explained by the common features of their evolution, especially by the existence of relict orphan groups. The fact that in Homilsha Forests the kurtosis and skewness of distributions decreases in the genera-families-orders row can therefore be explained by the relatively low percentage of the high-rank orphan taxa in the local biota. This may be a common feature of communities studied at small geographical scale, since orphan taxa often demonstrate a high level of endemism. Comparative studies of local communities from different climate zones may help to understand how universal are the patterns, described herein.

Keywords: Agaricomycetes; Aves; biota; biodiversity; Bryophyta; Coleoptera; distribution fitting; Eumycetozoa; fauna; flora; Insecta; Magnoliophyta; Myxogastrea; Myxomycetes; national park; nature conservation territories; species diversity.

\section{Introduction}

Taxonomic spectrum is a traditional term for the relation between supraspecific taxa by the number of included species (or other taxa) within a natural area (Scheiner, 2013). The description of taxonomic spectra with the naming of leading taxa serves as a part of a standard description of local communities and can be found in numerous articles on plant, animal, fungal and protist diversity (Bertrand et al., 2006; Leontyev et al., 2013; Brygadyrenko, 2015, 2016; Prylutskyi et al., 2017; Putchkov et al., 2019, 2020). The theoretical meaning of these data is usually ignored. However, within the molecular-phylogenetic paradigm, supraspecific taxa are considered as natural entities with verifiable statistical support and reliably delimited boundaries (Bacaro et al., 2007; Padial et al., 2010). Therefore, the relation between these branches by the number of included species is theoretically meaningful, and reflects the evolutionary history of both the local biota and the phylogenetic group (Chen, 2013; Barfknecht \& Gibson, 2021).

The separation of taxa based on the molecular-phylogenetic data has contributed substantially to understanding the natural boundaries between taxa and the patterns of speciation (Chapple \& Ritchie, 2013), while the accumulation curves for the known number of supraspecific taxa have passed the knee of the curve before 1950-s and now is very close to the asymptote of saturation for all ranks, except genera (Mora et al., 2011). It can be expected that the available data on the scope and delimitation of supraspecific taxa are representative, and their analysis will help to identify the biological patterns existing in nature (Desnoues et al., 2017). However, such an analysis is hampered by a number of historical and subjective factors, related to the classification of individual groups. The rank of taxon depends on the history of its study (for example, when sister branches already have a certain status, it determines the status of the new taxon), the presence of easily recognizable morphological features (Leontyev \& Fefelov, 2012), individual views of researchers, etc. (Bertrand et al., 2006). Different supraspecific taxa of a certain rank, though being perfectly monophyletic per se, are still incomparable if they are not sister taxa or were not established based on time-calibrated phylogenies. For example, the genus of bright-spored myxomycetes (Lucisporomycetidae) cannot be considered as a biological analogue of the genus of dark-spored myxomycetes (Columellomycetidae) even at the level of the variability of marker genes (Leontyev \& Schnittler, 2017; Borg Dahl et al., 2018), and the order of vertebrates can differ from the order of invertebrates by the age up to 400 myr (Holt \& Jønsson, 2014)

Since taxonomic spectra can be seen as mathematical distributions (Bacaro et al., 2007; Scheiner, 2013), some of their properties have been already investigated. Richness, diversity, dominance and evenness estima- 
tors for such spectra have repeatedly been reported, and the distributions were compared with each other using rank correlation coefficients (Leontyev, 2007). However, the distribution fitting for taxonomic spectra still issues many challenges. It is believed that most of the species abundance spectra (the ratio between species and number of specimens) may be described by one of four classical types of distribution: logarithmic, lognormal, exponential and broken stick (Magurran, 2004). Many other models have been proposed with different underlying ecological, mathematical or evolutionary assumptions (Matthews \& Whittaker, 2014). As for the distributions of species or other taxa within higher-rank taxa, they are known to correspond to so-called hollow-curve distributions, or HCDs (Dial \& Marzluf, 1989). These distributions usually include one or several leading taxa and a long trail of outsiders. The curvature of the distribution function graph usually depends on the taxonomic rank, increasing from phylum to genus (Dial \& Marzluff, 1989; Mora et al., 2011). With all that, the origin of these HCDs remains unclear. Some authors consider them as an artifact of extensive division of taxa, which occurred during the second half of 20th century. Others explain HDCs to be a result of the diversity of life history traits (body structure, rate of change of generations, etc.), which can stimulate the diversification of individual taxa or prevent it (Clayton, 1972; Dial \& Marzluff, 1989; Matthews \& Whittaker, 2014). It remains unknown whether the taxonomic spectra of different groups have different types of distributions, and to what extent the features of the distribution depend on the rank or on the attribution of the taxon to a particular phylogenetic group. A comprehensive assessment of the mathematical properties of the taxonomic spectrum, the identification of its inherent characteristics remains an important task.

The understanding of the taxonomic spectra reported in individual studies is greatly reduced by the incompleteness of primary data. The taxonomic spectrum of the local community is fundamentally influenced by the methods of detection of organisms e.g. season, duration and type of route (Leontyev et al., 2013; Yatsiuk et al., 2018), the species concept used (Leontyev \& Fefelov, 2012; Leontyev et al., 2014) etc. Therefore, it is important to study taxonomic spectra using large checklists that integrate the results of long-term research carried out by different authors and using different methods. In Ukraine, one of the rare examples of protected area where studies of plants, animals, fungi and protists have been systematically carried out for over a century is the Homilsha Forests National Nature Park (Prylutskyi et al., 2017). Taking this into consideration, in this paper we analyze taxonomic spectra for different groups of plants, animals, fungi and protists that occur in this territory, and describe their mathematical properties.

\section{Materials and methods}

The data for the taxonomic spectra of the analysed groups were taken from published checklists and annual reports of the Homilsha Forests National Park. The data on following taxa were included: (1) plants: Viri- diplantae: Magnoliophyta (Vlashchenko et al., 2010), Bryophyta (Barsukov, 2008); (2) animals: Metazoa: Coleoptera (Puchkov et al., 2010; Puchkov, 2018; Skrylnik \& Bieliavtsev, 2020), Aves (Vlashchenko et al., 2010); (3) fungi: Agaricomycetes (Prylutskyi et al., 2017); (4) protisits: Amoebozoa: Myxomycetes (Prylutskyi et al., 2017). The systematic lists of organisms, taken from the literature sources, have been revised according to the current phylogenetic classifications of Magnoliophyta (Angiosperm Phylogeny Group, 2016), Coleoptera (Löbl \& Smetana, 2003, 2004, 2006, 2007, 2008, 2010, 2011, 2013), Aves (del Hoyo \& Collar, 2018), Ascomycota (Wijayawardene et al., 2020) and Myxomycetes (Leontyev et al., 2019). After that, the number of species in each order, family and genus was determined for each taxonomic group. Since invertebrates are represented in our study exclusively by the order Coleoptera, only family and genus spectra were studied for this group. In total, the dataset comprised 2,349 species which occur in the Homilsha Forests, belonging to 1,121 genera, 331 families and 91 orders. The number of taxa included in the analysis for each taxonomic group is shown in Table 1.

The fitdistrplus package for R (https://cran.r-project.org/web/ packages/fitdistrplus/fitdistrplus.pdf) was used to calculate the mathematical characteristics of taxonomic spectra, including range, median, arithmetic mean, standard deviation, kurtosis and skewness. Fitting theoretical distributions to, including Fisher's log-series, lognormal, gamma, geometric, weibull and broken stick (Mattheus \& Whittaker, 2014) to our data was done with sads package for R (https://cran.r-project.org/web/packages/ sads/index.html). The completeness of the taxonomic spectra, and, accordingly, their suitability for further analyses was analysed using Chaol estimator with R package vegan (https://cran.r-project.org/web/packages/ vegan/vegan.pdf).

\section{Results}

The species accumulation curves indicate (Fig. 1) that the number of orders in all taxa found in the Homilsha Forests, except Bryophyta, have reached saturation and merge with the curve of predicted species number, estimated by the Chaol coefficient. The curves for the family spectra have passed the knee and show a tendency to approach the plateau, but remain significantly lower than the values predicted by Chaol. At the genus level curves show considerable steepness; for most taxa their dynamics is close to linear.

Taxonomic spectra of plants, animals, fungi and protists show quite different levels of variability and central values (Table 2). The median number of species was on average 7.1 for orders, 4.1 for families and 1.5 for genera. The standard deviation of the number of species averaged 31.4 for orders, 18.0 for families and 2.3 for genera. The values of the skewness coefficient averaged 2.4 for orders, 2.9 for families and 3.2 for genera, while the value of the kurtosis coefficient was 9.7 for orders, 15.8 for families and 19.8 for families.

Table 1

Number of species, genera, families and orders in analysed taxonomic groups, found in the Homilsha Forests

\begin{tabular}{lcccccc}
\hline \multicolumn{1}{c}{ Number of taxa } & Bryophyta & Magnoliophyta & Coleoptera & Aves & Agaricomycetes & Myxomycetes \\
\hline Species & 102 & 798 & 456 & 266 & 576 & 151 \\
Genera & 60 & 401 & 256 & 144 & 226 & 34 \\
Families & 30 & 99 & 55 & 59 & 76 & 12 \\
Orders & 13 & 34 & 1 & 19 & 16 & 8 \\
\hline
\end{tabular}

Table 2

Characteristics of taxonomic distributions in genera, families and orders for analysed taxonomic groups found in the Homilsha Forests

\begin{tabular}{|c|c|c|c|c|c|c|c|c|c|c|c|c|c|c|c|c|c|}
\hline \multirow{2}{*}{$\begin{array}{c}\text { Taxonomic } \\
\text { characteristics }\end{array}$} & \multicolumn{5}{|c|}{ Orders } & \multicolumn{6}{|c|}{ Families } & \multicolumn{6}{|c|}{ Genera } \\
\hline & $\mathrm{Br}$ & $\mathrm{Ma}$ & Av & $\mathrm{Ag}$ & My & $\mathrm{Br}$ & $\mathrm{Ma}$ & $\mathrm{Co}$ & $\mathrm{Av}$ & $\mathrm{Ag}$ & My & $\mathrm{Br}$ & $\mathrm{Ma}$ & $\mathrm{Co}$ & $\mathrm{Av}$ & $\mathrm{Ag}$ & My \\
\hline Range & 43 & 114 & 107 & 288 & 55 & 10 & 103 & 150 & 26 & 55 & 35 & 8 & 24 & 19 & 7 & 24 & 19 \\
\hline Median & 2.0 & 10.5 & 5.0 & 6.5 & 11.5 & 2.0 & 3.0 & 3.5 & 2.0 & 4.0 & 10.0 & 1.0 & 1.0 & 1.0 & 1.0 & 1.0 & 4.0 \\
\hline Mean & 7.85 & 23.47 & 13.84 & 36.00 & 18.88 & 3.40 & 8.06 & 16.29 & 4.51 & 7.58 & 12.58 & 1.70 & 1.99 & 1.78 & 1.83 & 2.56 & 4.44 \\
\hline Standard deviation & 11.57 & 29.20 & 25.40 & 72.28 & 18.39 & 2.94 & 15.16 & 63.29 & 5.60 & 9.48 & 11.36 & 1.33 & 2.28 & 1.95 & 1.46 & 2.90 & 3.96 \\
\hline Skewness & 2.65 & 1.82 & 3.15 & 3.22 & 1.19 & 1.06 & 3.91 & 6.49 & 2.44 & 2.50 & 0.88 & 2.67 & 4.39 & 4.89 & 2.03 & 3.48 & 1.76 \\
\hline Kurtosis & 10.95 & 5.83 & 13.77 & 14.11 & 3.84 & 2.70 & 21.60 & 47.48 & 9.14 & 10.97 & 2.84 & 11.40 & 30.89 & 35.14 & 6.71 & 20.06 & 7.28 \\
\hline
\end{tabular}

Note: Br-Bryophyta, Ma-Magnoliophyta, Co-Coleoptera, Ag-Agaricomycetes, Av-Aves, My-Myxomycetes. 
Visual assessment of the rank-abundance plots shows the similarity of studied taxonomic spectra to the HCDs at all levels (Fig. 2). Testing the correspondence of taxonomic spectra to null models according to the Akaike information criterion (AIC) has shown that the spectra of most taxa at all ranks are closely approximated by the log-series distribution model (Table 3). At the same time, in the genera-families-orders row the distribution becomes closer to the lognormal model. It is well seen in

Table 3

Delta Akaike information criterion values (dAIC) showing correspondence of taxonomic spectra to the distribution models

\begin{tabular}{|c|c|c|c|c|c|c|c|c|c|c|c|c|c|c|c|c|c|}
\hline \multirow{2}{*}{ Distribution type } & \multicolumn{3}{|c|}{ Agaricomycetes } & \multicolumn{2}{|c|}{ Coleoptera } & \multicolumn{3}{|c|}{ Aves } & \multicolumn{3}{|c|}{ Bryophyta } & \multicolumn{3}{|c|}{ Magnoliophyta } & \multicolumn{3}{|c|}{ Myxomycetes } \\
\hline & $\mathrm{O}$ & $\mathrm{F}$ & $\mathrm{G}$ & $\mathrm{F}$ & $\mathrm{G}$ & $\mathrm{O}$ & $\mathrm{F}$ & $G$ & $\mathrm{O}$ & $\mathrm{F}$ & $\mathrm{G}$ & $\mathrm{O}$ & $\mathrm{F}$ & $\mathrm{G}$ & $\mathrm{O}$ & $\mathrm{F}$ & $\mathrm{G}$ \\
\hline Broken stick & 16.0 & 16.7 & 216.8 & 44.0 & 216.8 & 14.2 & 26.8 & 105.9 & 8.1 & 7.4 & 45.7 & 0.6 & 76.8 & 314.1 & $0.0^{*}$ & $0.0^{*}$ & 6.0 \\
\hline Gamma & 9.5 & 20.2 & 145.7 & 36.2 & 145.7 & 12.4 & 30.3 & 55.5 & 10.8 & 8.8 & 21.5 & 2.7 & 67.5 & 238.7 & 6.5 & 5.6 & 7.9 \\
\hline Geometric & 13.6 & 7.6 & 36.2 & 32.4 & 36.2 & 12.0 & 14.1 & 8.9 & 7.2 & $0.0^{*}$ & 2.7 & 0.7 & 63.3 & 68.2 & 2.4 & 1.7 & $0.0^{*}$ \\
\hline Lognormal & 3.5 & 4.8 & 33.7 & 5.5 & 33.7 & 5.0 & 15.3 & 17.8 & 7.7 & 5.0 & 4.3 & $0.0^{*}$ & 21.0 & 68.0 & 7.3 & 7.3 & 6.0 \\
\hline Log-series & $0.0^{*}$ & $0.0^{*}$ & $0.0^{*}$ & $0.0^{*}$ & $0.0^{*}$ & $0.0^{*}$ & $0.0^{*}$ & $0.0^{*}$ & $0.0^{*}$ & 0.1 & $0.0^{*}$ & 1.5 & $0.0^{*}$ & $0.0^{*}$ & 5.5 & 3.7 & 2.7 \\
\hline Weibull & 7.2 & 19.3 & 193.0 & 28.1 & 193.0 & 10.3 & 30.3 & 76.8 & 10.1 & 9.9 & 33.2 & 2.0 & 56.6 & 292.5 & 6.5 & 5.6 & 8.6 \\
\hline
\end{tabular}

Note: asterisks $(*)$ indicate the best distribution model among tested for the rank and the taxonomic group; $\mathrm{O}-$ orders, $\mathrm{F}$ - families, $\mathrm{G}$ - genera.
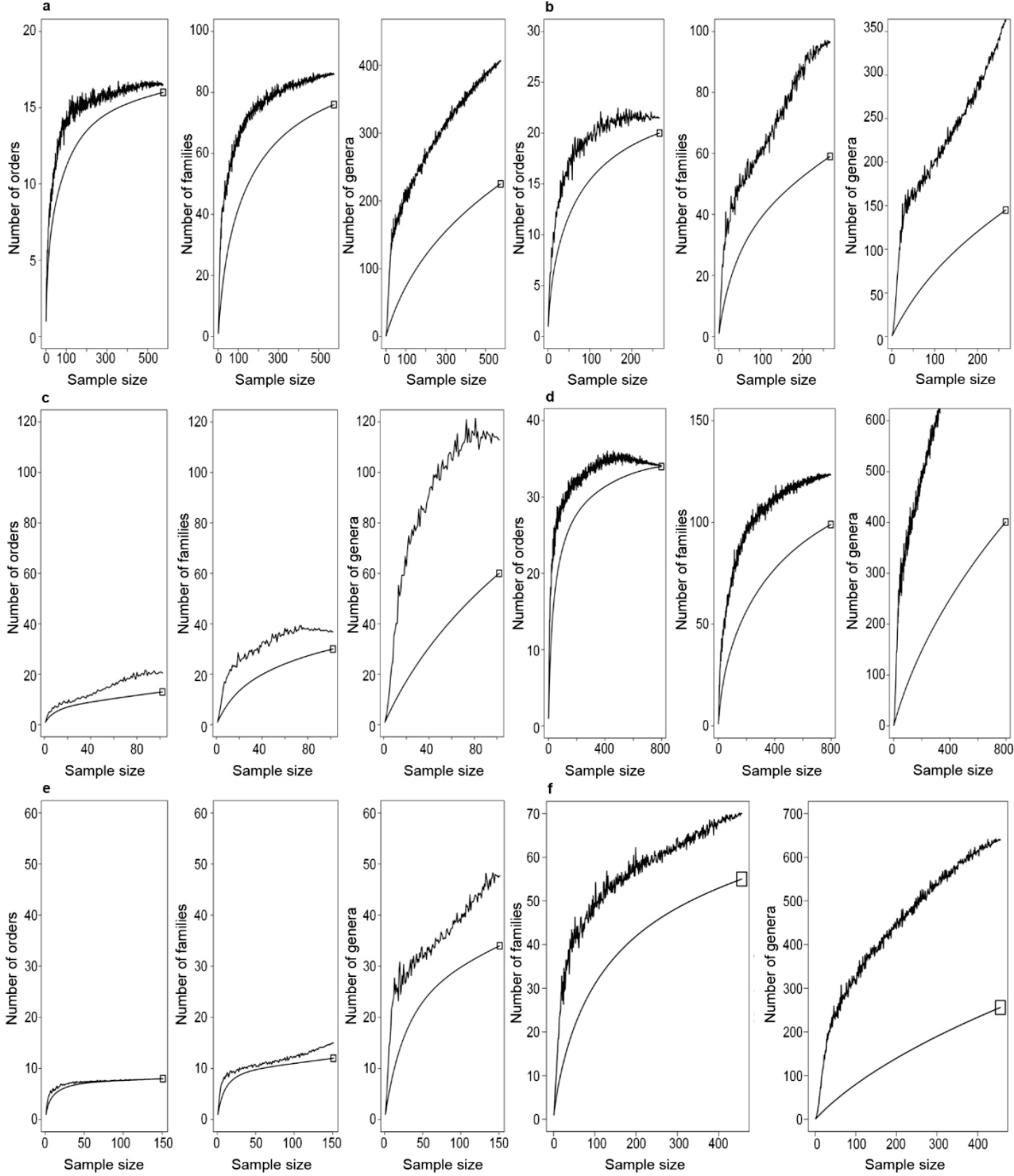

Fig. 1. Rarefaction curves of observed (plain line) and estimated by Chaol (jagged line) number of supraspecific taxa (orders, families and genera) in Homilsha Forests: $a$-Agaricomycetes; $b$-Aves; $c$-Bryophyta; $d$-Magnoliophyta; $e$-Myxomycetes; $f$-Coleoptera 


\section{Discussion}

The drastic changes in taxonomy that have occured during the recent decades theoretically should have made taxonomic spectra less similar to HDCs distributions, if this similarity was only an artifact of artificial taxon splitting. However, the data we obtained do not confirm this assumption. Despite the use of phylogenetically based classifications in our study, at the levels of genera, and sometimes at the family and order levels as well, the distribution curves have extremely high values of skewness and kurtosis. Such values correspond to the difference between taxa of the same rank by the number of included species in 2.0-2.5 orders of magnitude. We also did not observe any influence of the state of knowledge about the
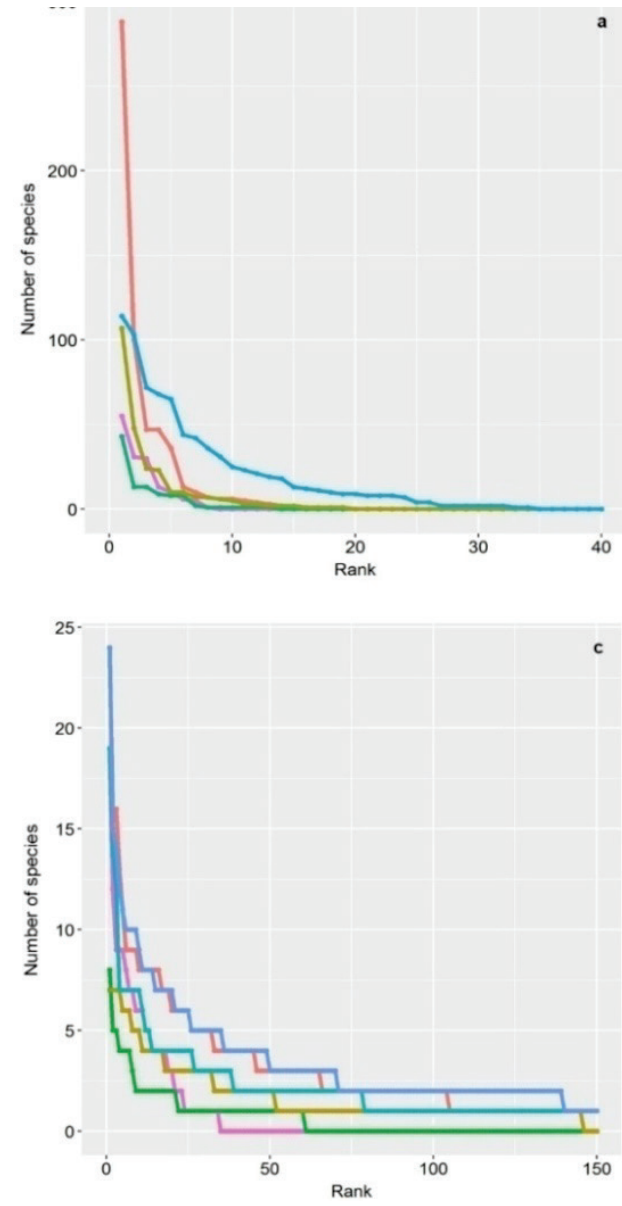

Fig. 2. Hollow-curve distributions at the levels of genera $(a)$, families $(b)$

The comparison of distributions at different ranks show that the indexes of skewness and kurtosis decrease in the genera-families-orders row. In other words, the share of monotypic and other small taxa is higher among genera, than among orders. However, taking into consideration the above-mentioned existence of monotypic superkingdoms, we cannot expect that if the rank of a taxon is higher, the proportion of monotypic subtaxa is smaller. Orphan taxa in most cases are the relictual basal groups, so their presence can be interpreted as a characteristic of the 'relictuality' of the whole group. This characteristic, however, is not identical to the evolutionary age of taxon. Orphan basal groups are known even in relatively young taxa like Aves and Magnoliophyta (Angiosperm Phlogeny Group, 2016; del Hoyo et al., 2018). However, they are not necessarily present in every local biota. This can be the source of the difference in the skewness value between Aves and Magnoliophyta, because the first group is represented in the Homilsha Forests by several orphan orders, and the second is not. Further study is needed to understand, whether there are any general patterns in the distribution of orphan taxa, but it is obvious that relictual groups are often endemics, and this may reduce their representation in local communities, especially outside the world biodiversity hot sports. At the same time, we must take into account the still existing trend to limit the number of higher taxa for practical reasons (Bertratnd et al., 2006). local diversity of the group on the distribution evenness. For example, Aves and Myxomycetes show similar distribution properties, although the first group is one of the most well-studied in the world (Mora et al., 2011), while the second one may include 10 or more undescribed cryptic species within one morphospecies (Shchepin et al., 2016; Shchepin et al., 2019; Lloyd et al., 2019). So we can assume that there are objective factors that help to maintain the hollow-curve distributions of taxonomic spectra. Interestingly, such patterns can be found even at the highest taxonomic levels worldwide. This may explain the phenomenon of micro-kingdoms, i.e. eukaryotic supergroups, whose rank is often equal to kingdom and higher, but the scope does not exceed one or two species (Brown et al., 2018; Lax et al., 2018; Adl et al., 2019).
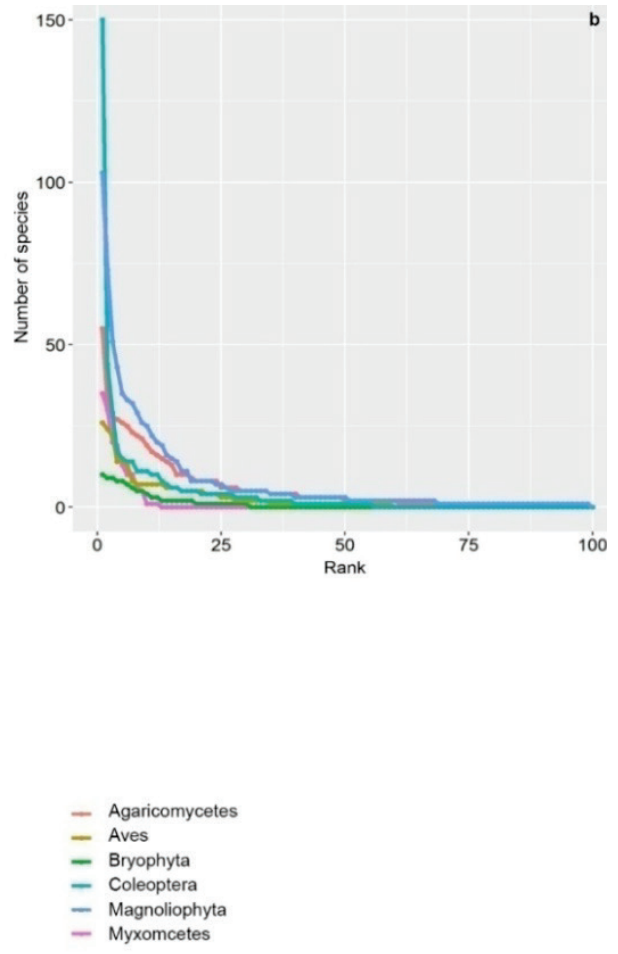

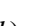

) and orders $(c)$ for the different taxonomic groups in Homilsha Forests

Small higher-rank groups are reluctantly created. This also can contribute to the curvatures reducing in the genera-families-orders row.

Among the studied types of distribution, the log-series model appears the most appropriate for the studied taxonomic spectra. This model is also typical for the species abundance spectra studied at small territories (Antão et al., 2021). Therefore, both taxonomic spectra and species abundance spectra show similar distribution patterns. However, taking into consideration the groups with the distribution different from the log-series model (Myxomycetes, Bryophyta), the limited territory cannot be the sufficient explanation for the patterns, described above. The state of knowledge about the local diversity of the group cannot plausibly explain it either, because the deviations from the log-series distribution do not appear in all ranks of a certain group. Additionally, non-log-series distributions are observed even in groups with very well-studied species composition (Magnoliophyta). Finally, the deviation from the log-series distribution cannot be explained by the conservative taxonomic traditions, because taxa that have shown high compliance with this model, as well as those that deviate from it, are represented by two types of groups, those with a traditionally conservative system of ranks (Aves, Magnoliophyta), and those in which the system of higher taxa has been radically revised on the basis of phylogenetic data in recent decades (Agaricomycetes, Myxomycetes). 

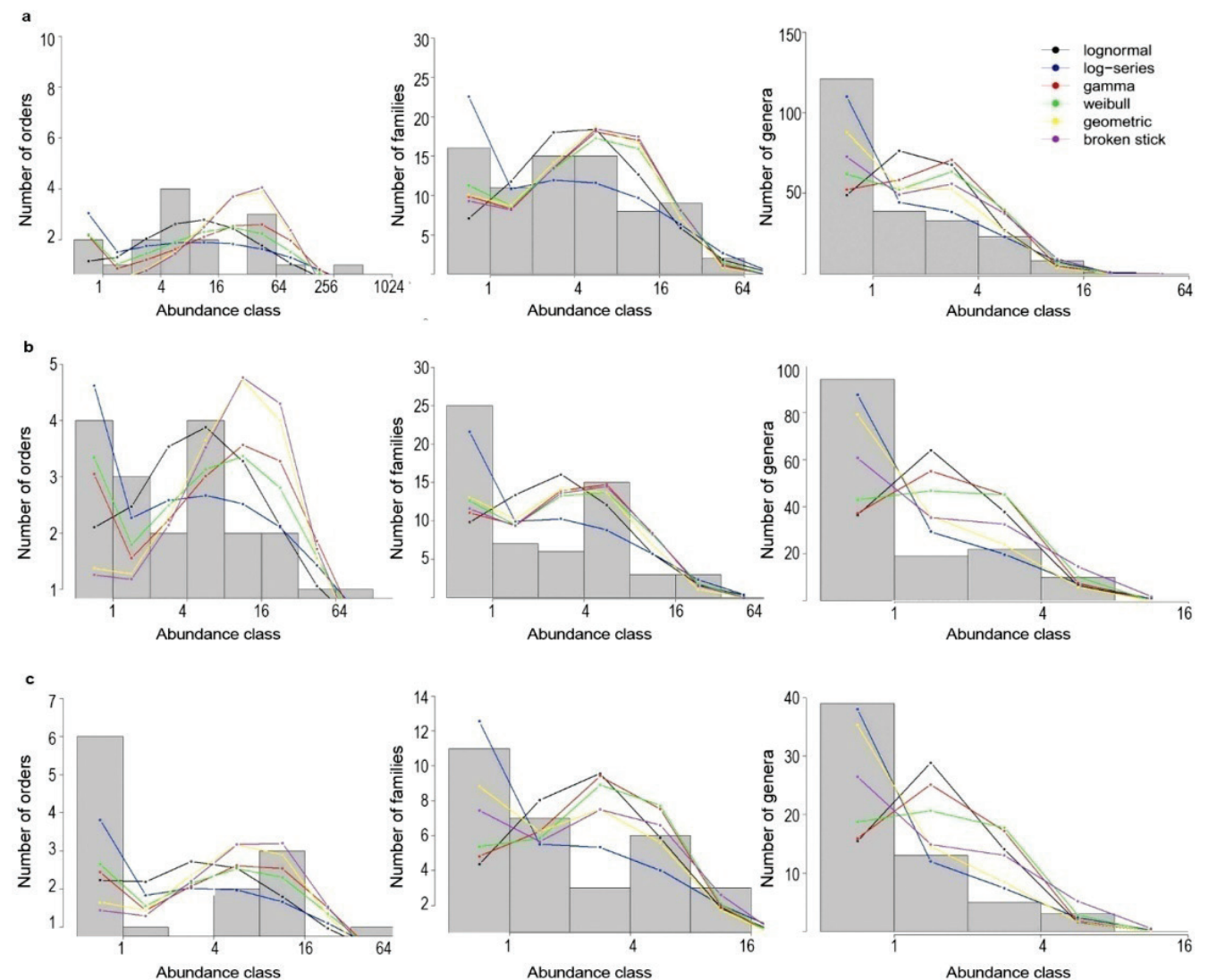

Fig. 3. Distribution fitting for taxonomic spectra of Agaricomycetes $(a)$, Aves $(b)$ and Bryophyta $(c)$ at the levels of genera, families and orders: grey columns show the observed number of taxa within abundance classes; coloured lines show estimated distribution models
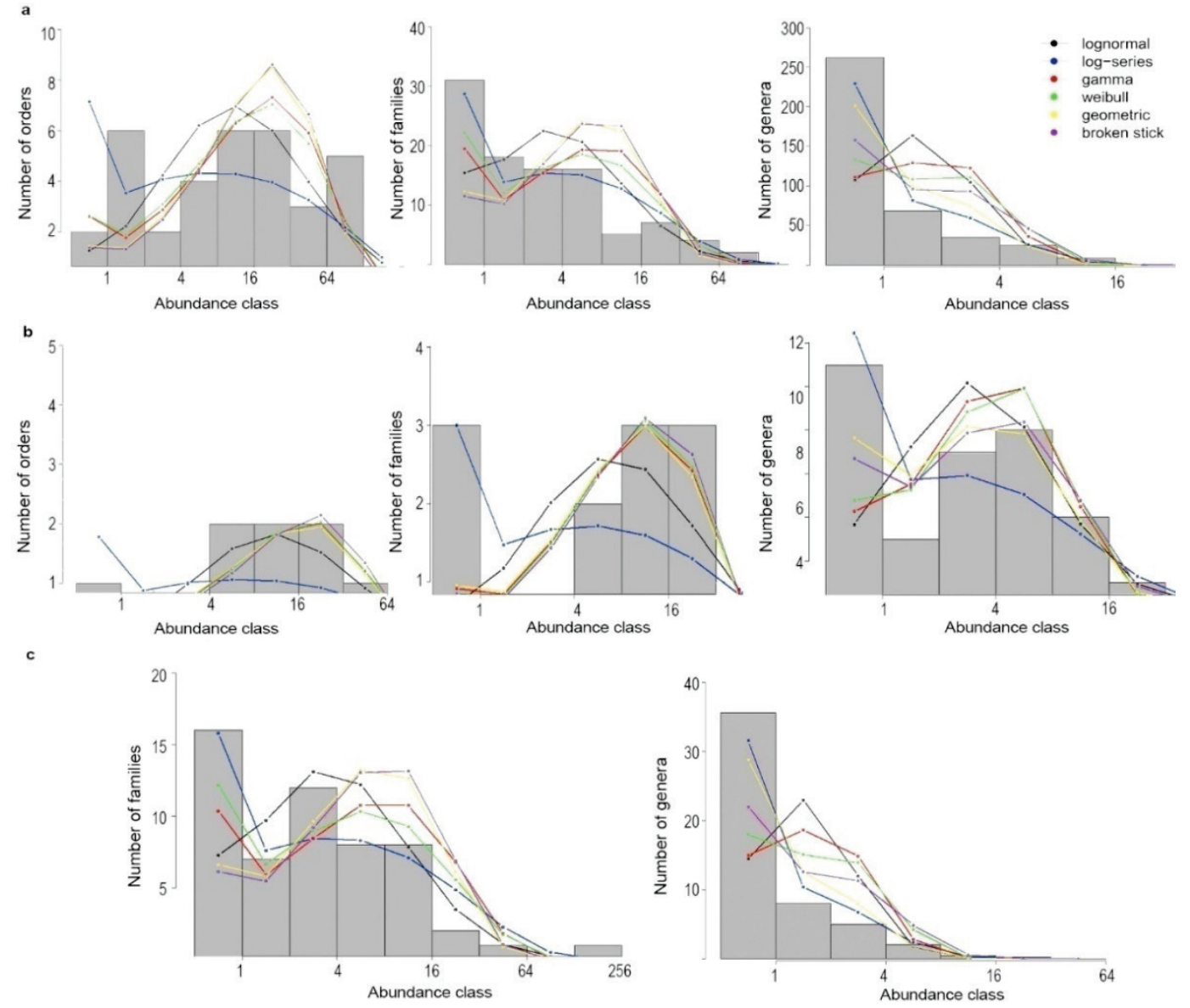

Fig. 4. Distribution fitting for taxonomic spectra of Magnoliophyta $(a)$, Myxomycetes $(b)$ and Coleoptera $(c)$ at the levels of genera, families and orders: grey columns show the observed number of taxa within abundance classes; coloured lines show estimated distribution models 
Some properties of taxonomic distributions in the local communities are consistent with the general patterns found in the global biota at different taxonomic ranks. In particular, this is the case of the rarefaction curves approaching the plateau, which get more prominent as the rank increases, as shown on Figure 1 (Mora et al., 2011). This means that phylogenetic relationships at the level of large lineages of the Tree of Life are now successfully reflected in the classification of living things (at least, for the macroorganisms), but the structure of genera in many groups still remains artificial and generally less understood.

\section{Conclusion}

Our data suggest the existence of common mathematical properties of local taxonomic spectra that are independent of the taxonomic position or rank of the taxon. At the same time, both factors have an impact on specific quantitative characteristics of distributions. For example, in the ordersfamilies-genera row the predicted level of knowledge about the number of taxa is systematically decreasing. The values of kurtosis and skewness, and the correspondence to the log-series distribution model, also show a variation, but without a clear trend. The hollow-curve distribution of taxonomic spectra is more likely not an artifact of taxonomic research, but reflects some natural factors, first of all the presence of orphan groups, which occupy a basal position in the phylogenetic tree. The kurtosis of the taxonomic spectrum largely depends on the presence of such taxa in the local biota, but the factors that affect their distribution remain unclear. Further studies, involving comparable datasets from different local areas, preferably from different climate zones, may help to understand how universal are the patterns, described here, and how the geographical factors affect the distribution of orphan taxa that probably has a fundamental impact on the structure of taxonomic spectra.

\section{References}

Adl, S. M., Bass, D., Lane, C. E., Lukeš, J., Schoch, C. L., Smimov, A., Agatha, S., Berney, C., Brown, M. W., Burki, F., Cárdenas, P., Čepička, I., Chistyakova, L., Campo, J., Dunthorn, M., Edvardsen, B., Eglit, Y., Guillou, L., Hampl, V., Heiss, A. A., Hoppenrath, M., James, T. Y., Karpov, S., Kim, E., Kolisko, M. Kudryavtsev, A., Lahr, D. J. G., Lara, E., Le Gall, L., Lynn, D. H., Mann, D. G., Massana i Molera, R., Mitchell, E. A. D., Morrow, C., Park, J. S., Pawlowski, J. W., Powell, M. J., Richter, D. J., Rueckert, S., Shadwick, L., Shimano, S., Spiegel, F. W., Torruella i Cortes, G., Youssef, N., Zlatogursky, V., \& Zhang, Q. (2019). Revisions to the classification, nomenclature, and diversity of Eukaryotes. Journal of Eukaryotic Microbiology, 66(1), 4-119.

Bacaro, G., Ricotta, C., \& Mazzoleni, S. (2007). Measuring beta-diversity from taxonomic similarity. Journal of Vegetation Science, 18, 793-798.

Barfknecht, D. F., \& Gibson, D. J. (2021). Taxonomic and phylogenetic composition show biotic resistance to exotic invasion in acid seep springs. Ecological Processes, 10,4 .

Barsukov, O. O. (2008). Do vyvchennia brioflory natsionalnoho pryrodnoho parku "Homilshanski lisy" [The study of the bryoflora in the Homilsha Forests, National Nature Park]. In: Hnatush, S., Prokopiv, A., \& Tselevych, M. (Eds.). Youth and Progress of Biology. LNU, Lviv. P. 84 (in Ukrainian).

Bertrand, Y., Pleijel, F., \& Rouse, G. W. (2006). Taxonomic surrogacy in biodiversity assessments, and the meaning of Linnaean ranks. Systematics and Biodiversity, 4, 149-159.

Borg Dahl, M., Brejnrod, A. D., Russel, J., Sørensen, S. J., \& Schnittler, M. (2019). Different degrees of niche differentiation for bacteria, fungi, and myxomycetes within an elevational transect in the German Alps. Microbial Ecology, 78(3), $764-780$.

Brown, M. W., Heiss, A. A., Kamikawa, R., Inagaki, Y., Yabuki, A., Tice, A. K., Shiratori, T., Ishida, K.-I., Hashimoto, T., Simpson, A., \& Roger, A. (2018). Phylogenomics places orphan protistan lineages in a novel eukaryotic supergroup. Genome Biology and Evolution, 10(2), 427-433.

Brygadyrenko, V. V. (2015). Evaluation of the ecological niche of some abundant species of the subfamily Platyninae (Coleoptera, Carabidae) against the background of eight ecological factors. Folia Oecologica, 42(2), 75-88.

Brygadyrenko, V. V. (2016). Influence of litter thickness on the structure of litter macrofauna of deciduous forests of Ukraine's steppe zone. Visnyk of Dnipropetrovsk University, Biology, Ecology, 24(1), 240-248.

Chapple, D. G., \& Ritchie, P. A. (2013). A retrospective approach to testing the DNA barcoding method. PLoS One, 8(11), e77882.

Chen, Y. (2013). An autoregressive model for global vertebrate richness rankings: Long-distance dispersers may have stronger spatial structures. Zoological Studies, 52, 57.
Clayton, W. D. (1972). Some aspects of the genus concept. Kew Bulletin, 27, 281-287.

del Hoyo, J., \& Collar, N. J. (2018). Handbook of the birds of the world and BirdLife International digital checklist of the birds of the world. Version 3. Lynx Edicions \& Bird Life International, Barcelona, Cambridge.

Desnoues, E., Ferreira de Carvalho, J., \& Zohner, C. M. et al. (2017). The relative roles of local climate adaptation and phylogeny in determining leaf-out timing of temperate tree species. Forest Ecosystems, 4, 26. оформите по правилам или удалите

Dial, K. P., \& Marzluff, J. M. (1989). Nonrandom diversification within taxonomic assemblages. Systematic Zoology, 38, 26-37.

Emerson, B. C., \& Hewitt, G. M. (2005). Phylogeography. Current Biology, 15(10), 367-371.

Holt, B. G., \& Jønsson, K. A. (2014). Reconciling hierarchical taxonomy with molecular phylogenies. Systematic Biology, 63, 1010-1017.

Jadoon, W. A., Nakai, R., \& Naganuma, T. (2013). Biogeographical note on Antarctic microflorae: Endemism and cosmopolitanism. Geoscience Frontiers, 4(6), 633-646.

Lax, G., Eglit, Y., Eme, L., Bertrand, E. M., Roger, A. J., \& Simpson, A. G. B. (2018). Hemimastigophora is a novel supra-kingdom-level lineage of eukaryotes. Nature, 564(7736), $410-414$.

Leontyev, D. V. (2007). Florystychnyi analiz u mikolohii [Biodiversity analysis in mycology]. Osnova, Kharkiv (in Ukrainian).

Leontyev, D. V., \& Fefelov, K. A. (2012). Nomenclatural status and morphological notes on Tubifera applanata sp. nov. Mycotaxon, 120(2), 247-251.

Leontyev, D. V., \& Schnittler, M. (2017). Phylogeny of myxomycetes. In: Rojas Alvarado, C., \& Stephenson, S. L. (Ed.). Myxomycetes. Biology, Systematics, Biogeography and Ecology. Elsevier, New York, Amsterdam. Pp. 83-106.

Leontyev, D. V., Dudka, I. O., Kochergina, A. V., \& Kryvomaz, T. I. (2012). New and rare myxomycetes of Ukraine 3. Forest and forest-steppe zone. Nova Hedwigia, 94, 335-354

Leontyev, D. V., Schnittler, M., \& Stephenson, S. L. (2014). Pseudocapillitium or true capillitium? A study of capillitial structures in Alwisia bombarda (Myxomycetes). Nova Hegwigia, 99, 441-451.

Leontyev, D. V., Schnittler, M., Stephenson, S., Novozhilov, Y. K., \& Shchepin, O. V. (2019). Towards a phylogenetic classification of myxomycetes. Phytotaxa, 399(3), 209-238.

Lloyd, S. J., Leontyev, D. V., \& Dagamac, N. H. (2019). Three new species of Tubifera from Tasmania and New South Wales. Phytotaxa, 414(5), 240-252.

Löbl, I., \& Smetana, A. (Eds.). (2003). Catalogue of Palaearctic Coleoptera. Vol. 1. Archostemata-Myxophaga-Adephaga. Apollo Books, Stenstrup.

Löbl, I., \& Smetana, A. (Eds.). (2004). Catalogue of Palaearctic Coleoptera. Vol. 2. Hydrophiloidea-Histeroidea-Staphylinoidea. Apollo Books, Stenstrup.

Löbl, I., \& Smetana, A. (Eds.). (2006). Catalogue of Palaearctic Coleoptera. Vol. 3. Scarabaeoidea-Scirtoidea-Dascilloidea-Buprestoidea-Byrrhoidea. Apollo Books, Stenstrup.

Löbl, I., \& Smetana, A. (Eds.). (2007). Catalogue of Palaearctic Coleoptera. Vol. 4 Elateroidea-Derodontoidea-Bostrichoidea. Lymexyloidea-Cleroidea-Cucujoidea. Apollo Books, Stenstrup.

Löbl, I., \& Smetana, A. (Eds.). (2008). Catalogue of Palaearctic Coleoptera. Vol. 5. Tenebrionoidea. Apollo Books, Stenstrup.

Löbl, I., \& Smetana, A. (Eds.). (2010). Catalogue of Palaearctic Coleoptera. Vol. 6. Chrysomeloidea. Apollo Books, Stenstrup.

Löbl, I., \& Smetana, A. (Eds.). (2011). Catalogue of Palaearctic Coleoptera. Vol. 7. Curculionoidea I. Apollo Books, Stenstrup.

Löbl, I., \& Smetana, A. (Eds.). (2013). Catalogue of Palaearctic Coleoptera. Vol. 8. Curculionoidea II. Brill, Leiden, Boston.

Magurran, A. E. (2004). Measuring biological diversity. Blackwell Publishing, New York.

Matthews, T. J., \& Whittaker, R. J. (2014). Fitting and comparing competing models of the species abundance distribution: Assessment and prospect. Frontiers in Biogeography, 6, 67-82.

Mora, C., Tittensor, D. P., Adl, S., Simpson, A. G. B., \& Worm, B. (2011). How many species are there on Earth and in the ocean? PLoS Biology, 9(8), e1001127.

Padial, J. M., Miralles, A., de la Riva, I., \& Vances, M. (2010). The integrative future of taxonomy. Frontiers in Zoology, 7(16), 1-14.

Prylutskyi, O. V., Akulov, O. Y., Leontyev, D. V., Ordynets, O. V., Yatsiuk, I. I., Usichenko, A. S., \& Savchenko, A. O. (2017). Fungi and fungus-like organisms of Homilsha Forests National Park, Ukraine. Mycotaxon, 132(3), 1-56.

Putchkov, A. V. (2018). Zhuki-zhuzhelitsyi (Coleoptera, Carabidae) transformirovannyih tsenozov Ukrainyi [Ground-beetles (Coleoptera, Carabidae) of transformed cenoses of Ukraine]. DonNU, Kyiv (in Russian).

Putchkov, A. V., Brygadyrenko, V. V., \& Markina, T. Y. (2019). Ground beetles of the tribe Carabini (Coleoptra, Carabidae) in the main megapolises of Ukraine. Vestnik Zoologii, 53(1), 3-12.

Putchkov, A. V., Brygadyrenko, V. V., \& Nikolenko, N. Y. (2020). Ecologicalfaunistic analysis of ground beetles and tiger beetles (Coleoptera: Carabidae, $\mathrm{Ci}$ cindelidae) of metropolises of Ukraine. Biosystems Diversity, 28(2), 163-174. 
Putchkov, A. V., Markina, T. Y., \& Tolkach, I. A. (2010). Preliminary review of ground beetles (Coleoptera: Carabidae) of Nation Natural Park Gomolshanskie Lesa. The Kharkov Entomological Society Gazette, 18(2), 5-9.

Rojas, C., \& Stephenson, S. L. (Eds.). (2017). Myxomycetes. Biology, systematics, biogeography and ecology. Elsevier, New York, Amsterdam.

Scheiner, S. M. (Ed.). (2013). Encyclopedia of Biodiversity. Elsevier, New York, Amsterdam.

Shchepin, O. N., Novozhilov, Y. K., \& Schnittler, M. (2016). Disentangling the taxonomic structure of the Lepidoderma chailletii-carestianum species complex (Myxogastria, Amoebozoa): Genetic and morphological aspects. Protistology, 10(4), 117-129.

Shchepin, O. N., Schnittler, M., Dagamac, N. H. A., Leontyev, D. V., \& Novozhilov, Y. N. (2019). Unexplored diversity of microscopic myxomycetes: Evidence from environmental DNA. Plant Ecology and Evolution, 152(3), 499-506.

Skrylnik, Y. Y., \& Bieliavtsev, M. P. (2020). Beetles (Coleoptera) of National Nature Park "Gomilshansky Lisy" according to catches by window traps. Ukrainian Entomological Joumal, 18, 20-29.

The Angiosperm Phylogeny Group (2016). An update of the Angiosperm Phylogeny Group classification for the orders and families of flowering plants: APG IV. Botanical Journal of the Linnean Society, 181(1), 1-20.
Vlashchenko, S. V., Saidakhmedova, N. B., Honcharov, H. L., Yatsiuk, Y. O., Prylutskyi, O. V., Viter, S. V., Vlashchenko, A. S., \& Akulov, O. Y. (2010). Litopys pryrody Natsionalnoho pryrodnoho parku Homilshanski lisy [Chronicle of nature of the Homilsha Forests National Nature Park]. Vol. 6. V. N. Karasin Kharkiv National University, Kharkiv (in Ukrainian).

Wijayawardene, N. N., Hyde, K. D., Dai, D. Q., Tang, L. Z., Aptroot, A., CastañedaRuiz, R. F., Dru-zhinina, I. S., Cai, F., Ekanayaka, A. H., Erdoğdu, M., Fiuza, P. Gentekaki, E., Goto, B., Haelewa-Ters, D., Hongsanan, S., Jeewon, R., Kirk, P., Jayalal, U., Karunarathna, S. C., Lumbsch, T., Madrid, H., Maharachchikumbura, S. S. N., Monteiro, J. S., Shivaprakash, N., Pfliegler, W. P., Phillips, A. J. L., Saxena, R. K., Stadler, M., Tian, Q., Tokarev, Y. S., Tsurykau, A., Ertz, D., Lee, H. B., Etayo, J., Vizzini, A., Jones, E. G. B., Lin, C. G., Li, W., Dai, Y. C., Fan, X. L., McKenzie, E. H. C., Shivas, R. G., Hustad, V., Leontyev, D. V. de Hoog, G. S., Niskanen, T., Boekhout, T., Gaya, E., \& Thines, M. (2020). A dynamic portal for a community-driven, continuously updated classification of Fungi and fungus-like organisms. Mycosphere, 11(1), 1514-1526.

Yatsiuk, I. I., Leontyev, D. V., \& Shlakhter, M. (2018). Myxomycetes of National Nature Park Slobozhanskiy (Ukraine): Biodiversity and noteworthy species. Nordic Journal of Botany, 1, e01605. 